\title{
Evaluation of the Circular-Spiral Structure of Teaching-Learning- Assessment in an ICT Environment
}

\author{
Noga Magen-Nagar \\ Gordon College of Education
}

\begin{abstract}
In the digital era the process of structuring knowledge is perceived as a circular-spiral continuum of learning-directed instruction, active reflective learning, and performance-based contextual evaluation following the new International Computer and Information Literacy Study (ICILS). This research explores the extent to which the teacher's mastery of Computer and Information Literacy (CIL) influences the process of structuring knowledge in an Information and Communication Technology (ICT) environment. The study encompassed 203 teachers who participated in the national ICT program in Israel "Adapting the education system to the 21st century". SEM analysis finds that the process of structuring knowledge in an ICT environment is circular and includes the use of ICT teaching strategies, learning to write in an ICT environment, and alternative ICT assessment. This process is clearly influenced by the level of the teacher's mastery of computer literacy and knowledge for each of the components of its structuring. The research findings note the complexity of the process of structuring knowledge in an ICT environment and emphasize the importance of the dependency between all the components of the process and the teacher's mastery of CIL. Following the research findings we recommend the continuous, direct and explicit development and promotion of CIL amongst the teachers as an integral part of the process of their professional development in this changing reality.
\end{abstract}

\section{Introduction}

During the years that passed since the onset of the technological revolution, schools have undergone numerous organizational and pedagogical changes [11]. Structuring the student's knowledge is considered a central process in digital-age learning. It is perceived as a circular-spiral continuum of teaching which directs towards learning, active and reflexive learning, and contextual performance-based assessment [2].

Learning environment which is based on the constructivist approach is characterized by teacherstudent and student-student interactions about the content in a certain context. The quality of those

processes influences the students' achievements [5]. Therefore, it is expected, that in a learning environment, which integrates various digital technologies, the learning methods would be directed to developing life skills, experience in investigation and problem solving, accepting responsibility, and cooperation, which requires interaction and mediation [6]. The technological abilities of gathering, managing, creating and sharing information permit to realize numerous opportunities for innovative constructivist learning [16], where the students are involved and participate actively in a meaningful learning process. They reorganize their experiences through achieving new ones, thus laying a foundation for more complex future experiences.

With this in mind, the current Israeli nation-wide program of ICT, "Adapting the Educational System to the 21st Century", has emphasized the development of ICT skills, both on student and teacher level [17]. The basic assumption is that the teacher, who prepares his student to effective coping with the 21 st century challenges, is fluent in the skills which are necessary to the students. Those skills include ICT literacy, high-order thinking (creative and critical thinking and problem solving), teamwork, and independent learning [17]. The present study focuses on the teachers' knowledge in computer and information literacy.

\section{Computer and Information Literacy (CIL)}

An international study was performed in 2013 in order to assess computer and information literacy (CIL) skills of eight-graders. The survey also collected data on the teachers' professional development policy and on the requirement to guide the teachers toward CIL mastery [8].

CIL is an extensive field of knowledge, skills, and understanding, which are essential to creating and managing communication beyond the limit of acquaintance [4]. It is defined as "an individual's ability to use computers to investigate, create and communicate in order to participate effectively at home, at school, in the workplace and in society" [9, p. 17].

According to ICILS [9], The CIL construct was conceptualized in terms of two strands that framed 
the skills and knowledge addressed by the CIL instruments. Each strand was made up of several aspects, each of which referenced specific content.

1. Collecting and managing information: focuses on the receptive and organizational elements of information processing and management. It incorporates three aspects:

1.1. Knowing about and understanding computer use: This refers to a person's declarative and procedural knowledge of the generic characteristics and functions of computers. It focuses on the basic technical knowledge and skills that underpin our use of computers in order to work with information.

1.2. Accessing and evaluating information: This refers to the investigative processes that enable a person to find, retrieve, and make judgments about the relevance, integrity, and usefulness of computerbased information.

1.3. Managing information: This aspect refers to the capacity of individuals to work with computerbased information. The process includes ability to adopt and adapt information-classification and information-organization schemes in order to arrange and store information so that it can be used or reused efficiently.

2. Producing and exchanging information: Focuses on using computers as productive tools for thinking, creating, and communicating. The strand has four aspects:

2.1. Transforming information: This refers to a person's ability to use computers to change how information is presented so that it is clearer for specific audiences and purposes.

2.2. Creating information: This aspect refers to a person's ability to use computers to design and generate information products for specified purposes and audiences. These original products may be entirely new or they may build on a given set of information in order to generate new understandings.

2.3. Sharing information: This aspect refers to a person's understanding of how computers are and can be used as well as his or her ability to use computers to communicate and exchange information with others.

2.4. Using information safely and securely: This refers to a person's understanding of the legal and ethical issues of computer-based communication from the perspectives of both the publisher and the consumer of that information.

Each of the skills necessitates the use of suitable production tools, such as file managing, word processing, slideshows, electronic spreadsheets, internet, information and communication [9].

Computer literacy is the technical ability to use the technical computer procedures. Information literacy is an intellectual ability, which emphasizes the processes of information management and evaluation, and the ability to use it effectively [4].
The processes of information literacy occur at the stages of receiving, processing, and transfer, while computer literacy is relevant to the stages of receiving and transfer. The literature review shows that computer and information literacies have merged into the concept of ICT. However, there is no consensus about the method of teaching this literacy. In the ICILS framework, the conceptual structure of computer and information literacies is closely related to ICT and digital literacy, but at the same time, it is defined separately [7].

The ICILS survey was conducted on approximately 60,000 students and 35,000 teachers in 21 countries. Its findings indicated that teachers who integrated ICT in their teaching were those who reported ICT mastery. Sixty percent of the teachers reported that they use computers at least once a week for teaching purposes, while $80 \%$ reported using computers on a weekly basis in their work. In general, the teachers were confident in their abilities to use a variety of computer applications. Moreover, $70 \%$ of the teachers expressed confidence in their ability to use computer applications for student evaluation and progress tracking [8].

\section{Teaching-Learning-Assessment in an ICT Environment}

Teaching in an ICT environment is an innovative pedagogy. It requires the teachers to possess professional knowledge, which incorporates the ability to apply high-quality teaching-learningassessment processes. Additionally, this pedagogy demands that the teachers be able to independently build learning activities, which combine computer and information literacy, and are based on the general and practical principles of the constructivist approach.

Fullan [10] defines three gradual dimensions of change in a teacher's application of the digital learning and teaching. The first is using new hardware and software components. Next, teaching and learning are practiced in new ways. And lastly, there is a change in beliefs and insights. Fullan states, that the combination of new ways of teaching and novel technology is capable to elicit an action potential not only among students, but among the teachers themselves as well [10]. Thus, the teachers are motivated toward more meaningful and profound work.

In the literature, technology integration in teaching-learning-evaluation is described as a gradual and hierarchical process, comprising three major steps. First, technology has to be "domesticated", in order to suit the existing teachinglearning habits. This is the initial and vital step of the implementation process (Salomon, 2000). It includes a first-order change, manifested by acquiring the necessary mastery in technology, while the 
pedagogical application preserves the familiar traditional approach. That is to say, the technology serves as an advanced demonstration tool, beyond "chalk and board" or written and drawn placards. As teachers' mastery of technology develops, the use of technological means in the classroom broadens. Computer presentations of information appear, along with interactive worksheet sent to students, use of the web in order to augment the existing textbooks, films and slideshows screening in the class, etc. However, in this stage, the use of technology is still essentially technical [15].

The next stage is a second-order change. It is manifested by implementation of the pedagogical rational of optimal digital learning, which is based on community, knowledge structuring, and intelligent use of digital communication. This communication exist between teacher and students and among the students, and is characterized by structuring the communal knowledge via on-line sharing tools and by making routine use of the digital information, available to all students at all times and places [12]. In order to attain this stage, teachers undergo significant professional development processes and empowering personal experiences. Such experiences may encourage the teachers to adopt student-focused teaching approaches and encourage experiments with authentic research methods, independent knowledge structuring, and cooperative activities among the students [6]. At this stage, technology becomes valuable for teachers, as it plays a vital role in their teaching process. Several studies have shown that the majority of teachers regard technology as improving their performance [15], [16]. Teachers report that digital tools make teaching-learning-evaluation more updated, authentic and relevant to the students. However, the conclusions of the researches are that this does not yet lead to the expected pedagogical change, which requires learning in a social cooperative context, while making use of the technological means [19], [20]. At present, information and communication technology integration in teaching is largely based on surfing in various websites, in order to find information and process it on a relatively simple level [3], [8], [12], [19].

The third stage is student-focused. It develops in an abundant and up-to-date on-line learning environment. The teacher has to find a way to integrate curriculum with novel technology tools, based on the unique properties of these tools. One should carefully plan the ways of using the tools, the level of synchronization, and the cooperation needed to reach the goals and the requirements of the study assignment [6]. This change might arrive through the cooperative knowledge structuring tools, made available by the Web 2.0 technology. It permits a wide spectrum of cooperative and individual work, according to the study assignment needs. Tools such as Wiki, Moodle, Google Docs, and Office365, provide options for knowledge structuring, socialization, and up-to-date digital communication. They allow the students to share with their peers various information items via textual, visual, and audio media. All the members of the learning community can add, edit, comment, or react to the information. This technological development leads to optimal digital learning, where students are constantly actively involved in the learning process. Twenty-first century technology based learning environments provide to the students opportunities for in-depth content research, independent problem solving, meaningful interpersonal connections, and renewal and nurturing of thinking [18].

In light of the technological development in education, Koehler and Mishra have broadened the concept of "teachers' knowledge" [14]. They added to the concept new realms of technological, pedagogical, and content knowledge (TPACK). This knowledge characterizes the teacher's ability to intelligently integrate technology in the teachinglearning-evaluation process. TPACK facilitates the processes of integration, thus promoting constructivist student-focused pedagogy [3], [13], [14].

Research has shown that teachers need to possess CIL mastery in order to implement technological tools in their teaching. However, teachers' training and professional development focus more on the pedagogical context and less on technological literacy [11], [14]. Apparently, a teacher's CIL mastery may promote the teaching-learningevaluation connections he creates on all three levels of the student knowledge structuring in a computerized environment.

\section{Research hypothesis}

The more a teacher has mastery of CIL, the more the process of the knowledge structuring in an ICT environment will be pronounced. The process will include four stages:

1. The teacher will use more varied ICT teaching strategies.

2. The teaching of writing in an ICT environment will be more extended.

3. More ICT alternative assessment methods will be employed.

4. The tools for pedagogical management will be more extensively used.

\section{Method}

\section{1 participants}

The research consisted of 203 teachers in primary schools, who joined the nation-wide ICT program, 
"Adapting the Educational System to the $21^{\text {st }}$ Century" in the beginning of the current school year (2013-4). The participants' mean experience in teaching was approximately 12 years $(\mathrm{M}=11.80$, $\mathrm{SD}=8.08)$. Most had undergraduate academic degree (76\%), while $17 \%$ had graduate degree.

\subsection{Instruments}

Teachers were asked to fill in a questionnaire that was composed of two main components: computer and information literacy and teaching characteristics in an ICT environment. A questionnaire was developed as a part of the national ICT program [17] that was based on Fraillon and Ainley [7]. The teachers were asked to respond to the questions using a 4-point Likert scale ranging from "not at all" (1) to "to a very great extent" (4). Table 1 presents the details of the questionnaire.

Table 1. The research questionnaire

\begin{tabular}{|c|c|c|c|c|}
\hline $\begin{array}{l}\text { Compon } \\
\text { ent }\end{array}$ & $\begin{array}{l}\text { Sub- } \\
\text { component }\end{array}$ & Item example & $\begin{array}{l}\text { No. } \\
\text { ite } \\
\text { ms }\end{array}$ & $\begin{array}{l}\text { Cronbac } \\
\text { h's } \\
\text { alpha }\end{array}$ \\
\hline \multirow{3}{*}{\multicolumn{2}{|c|}{$\begin{array}{l}\text { Computer and } \\
\text { Information Literacy } \\
\text { Managing } \\
\text { files }\end{array}$}} & & $1-$ & 96 \\
\hline & & & 28 & \\
\hline & & $\begin{array}{l}\text { Organizing, } \\
\text { locating, and } \\
\text { seeking } \\
\text { information in } \\
\text { folders on the disk } \\
\text { on key (item } 1 \text { ) }\end{array}$ & $1-4$ & 82 \\
\hline & $\begin{array}{l}\text { Word } \\
\text { processing }\end{array}$ & $\begin{array}{l}\text { Adding table and } \\
\text { its design, text } \\
\text { wrap, return to } \\
\text { headings (item 8) }\end{array}$ & $\begin{array}{l}5- \\
10\end{array}$ & 90 \\
\hline & $\begin{array}{l}\text { Preparing a } \\
\text { presentation }\end{array}$ & $\begin{array}{l}\text { Creating slides } \\
\text { comprising text, } \\
\text { graphics, pictures } \\
\text { (item 11) }\end{array}$ & $\begin{array}{l}11- \\
14\end{array}$ & 92 \\
\hline & $\begin{array}{l}\text { Electronic } \\
\text { spreadsheet }\end{array}$ & $\begin{array}{l}\text { Use of simple } \\
\text { functions: average, } \\
\text { sum (12) }\end{array}$ & $\begin{array}{l}15- \\
18\end{array}$ & 95 \\
\hline & $\begin{array}{l}\text { Internet } \\
\text { surfing }\end{array}$ & $\begin{array}{l}\text { Downloading/savi } \\
\text { ng files and } \\
\text { pictures from the } \\
\text { internet (item 21) }\end{array}$ & $\begin{array}{l}19- \\
22\end{array}$ & 88 \\
\hline & $\begin{array}{l}\text { Network } \\
\text { communicat } \\
\text { ions }\end{array}$ & $\begin{array}{l}\text { Writing responses } \\
\text { in a forum or blog } \\
\text { (item 28) }\end{array}$ & $\begin{array}{l}23- \\
28\end{array}$ & 88 \\
\hline $\begin{array}{l}\text { Teaching } \\
\text { in an ICT }\end{array}$ & $\begin{array}{l}\text { haracteristics } \\
\text { invironment }\end{array}$ & & $\begin{array}{l}29- \\
48 \\
\end{array}$ & .94 \\
\hline & $\begin{array}{l}\text { Using the } \\
\text { Computeriz } \\
\text { ed system } \\
\text { for } \\
\text { pedagogic } \\
\text { managemen } \\
\mathrm{t}\end{array}$ & $\begin{array}{l}\text { Use of } \\
\text { Manbass/MANBA } \\
\text { SSON / other } \\
\text { pedagogic } \\
\text { management tools } \\
\text { (item 29) }\end{array}$ & $\begin{array}{l}29- \\
31\end{array}$ & .88 \\
\hline
\end{tabular}

\begin{tabular}{|c|c|c|c|c|}
\hline $\begin{array}{l}\text { Compon } \\
\text { ent }\end{array}$ & $\begin{array}{l}\text { Sub- } \\
\text { component }\end{array}$ & Item example & $\begin{array}{l}\text { No. } \\
\text { ite } \\
\text { ms }\end{array}$ & $\begin{array}{l}\text { Cronbac } \\
\text { h's } \\
\text { alpha }\end{array}$ \\
\hline & $\begin{array}{l}\text { ICT } \\
\text { teaching } \\
\text { strategies }\end{array}$ & $\begin{array}{l}\text { I usually give my } \\
\text { students } \\
\text { computerized } \\
\text { assignments } \\
\text { intended for } \\
\text { practice and } \\
\text { repetition, for } \\
\text { solving problems } \\
\text { and for using } \\
\text { sources of } \\
\text { information (item } \\
\text { 34) }\end{array}$ & $\begin{array}{l}32- \\
36\end{array}$ & .84 \\
\hline & $\begin{array}{l}\text { Writing in } \\
\text { an ICT } \\
\text { Environmen } \\
\mathrm{t}\end{array}$ & $\begin{array}{l}\text { I offer my students } \\
\text { shared writing } \\
\text { tasks using tools } \\
\text { that enable shared } \\
\text { writing such as } \\
\text { discussion groups, } \\
\text { wiki, blogs (item } \\
\text { 41) }\end{array}$ & $\begin{array}{l}37- \\
42\end{array}$ & .85 \\
\hline & $\begin{array}{l}\text { ICT } \\
\text { Alternative } \\
\text { Assessment }\end{array}$ & $\begin{array}{l}\text { I provide feedback } \\
\text { to my students } \\
\text { using ICT tools } \\
\text { such as email, } \\
\text { forums, blogs, } \\
\text { wiki (item 47) }\end{array}$ & $\begin{array}{l}43- \\
48\end{array}$ & .88 \\
\hline
\end{tabular}

Additionally, some background data of the participants was collected, such as education and years of teaching experience. (See questionnaire in appendix 1: details of the questionnaire indices).

\subsection{Procedure}

The teachers answered the questionnaires in the framework of school in-service training intended for professional development in the realm of ICT, doing so online in the beginning using the Google Docs application. The aim of the research was explained to the teachers at the start of the questionnaire, and processes to ensure anonymity and privacy were explained. The time it took to fill out the questionnaire was around 30 minutes. All ethical guidelines were following.

\section{Results}

In order to test the research hypothesis we performed Pearson's correlation tests between CIL mastery and the components of the knowledge structuring process in an ICT environment (see Table 2).

Table 2. Pearson's correlations between the research variables $(\mathrm{N}=203)$

\begin{tabular}{lllllll}
\multicolumn{7}{c}{ variables $(\mathrm{N}=203)$} \\
& 1 & 2 & 3 & 4 & $\mathrm{M}$ & $\mathrm{SD}$ \\
\hline 1. CIL mastery & & & & & 3.29 & 0.61
\end{tabular}




$$
\begin{array}{lll}
\begin{array}{l}
\text { 2. ICT teaching } \\
\text { strategies }
\end{array} & .57^{* *} & \\
\text { 3. Teaching } & & \\
\text { Writing in an } & .53^{* *} & .73^{* *} \\
\text { ICT environment }
\end{array}
$$

\begin{tabular}{|c|c|c|c|c|c|c|}
\hline $\begin{array}{l}\text { 4. ICT } \\
\text { Alternative } \\
\text { Assessment }\end{array}$ & $.48^{* * *}$ & $.66^{* *}$ & $.74^{* *}$ & & & \\
\hline $\begin{array}{l}\text { 5. Using the } \\
\text { computerized } \\
\text { system for } \\
\text { Pedagogic } \\
\text { Management }\end{array}$ & $.56^{* * *}$ & $.49 * *$ & $.44^{* *}$ & $.40^{* * *}$ & $\begin{array}{l}2.03 \\
2.84\end{array}$ & $\begin{array}{l}0.82 \\
0.95\end{array}$ \\
\hline
\end{tabular}

Table 2 shows that there were strong positive significant correlations between teachers' CIL and the components of knowledge structuring in an ICT environment. That is to say, the higher a teacher's computer and information literacy was, the more his ICT teaching strategies were varied, his level of teaching writing in an ICT environment was advanced, his student assessment was more alternative and performed in an ICT environment, and his use of the computerized system for pedagogic management was more extensive. The vice versa was equally true. Strong positive significant correlations were found also between the components of the knowledge structuring in an ICT environment components.

In order to test the influence of CIL on the process of knowledge structuring in an ICT environment, a SEM (Structural Equation Modeling) was performed. For this analysis, the statistical software AMOS 22.0 (Analysis of Moment Structures) was employed [1]. This is a multivariable analysis in a graphic environment, which is used to test complex models, containing many variables or interactions between variables.

The results provided by the model measurements showed, that the value of $\chi^{2} \quad(\mathrm{df}=1) 0.41$ was not statistically significant $(\mathrm{p}=.522)$. RMSEA index (.000) was less than .05. NFI index (.999) and CFI (1.000) were very high. These findings indicate an excellent model fit.

Next, the structural model was tested in order to classify the interactions between the variables (see Figure 1).

Figure 1 shows that CIL mastery and the use of the computerized system for pedagogic management explain more of half of the variability of employing ICT teaching strategies (51\%). CIL mastery and the use of ICT teaching strategies explain more than half of the variability of teaching writing in an ICT environment (55\%). CIL mastery and teaching writing in an ICT environment explain more than half of the variability of ICT alternative assessment (55\%). CIL mastery and ICT alternative assessment explain approximately one third of the variability of the use of the computerized system for pedagogic management $(34 \%)$. This means that the variables, which were included in the model, adequately explain every component of the process of knowledge structuring in an ICT environment.

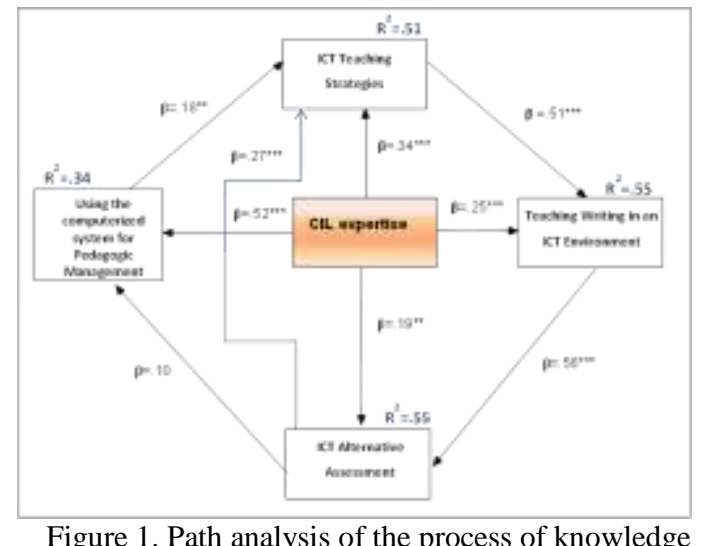
structuring in an ICT environment

When testing the path coefficients, Figure 1 shows that the variable "CIL mastery" has significant positive influences on the components of the process of knowledge structuring in an ICT environment. The influence with the highest power is on the use of the computerized system for pedagogic management $\left(\beta=.52^{* * *}\right)$, followed by the influences on ICT teaching strategies $\left(\beta=.34^{* * *}\right)$, teaching writing in an ICT environment $\left(\beta=.25^{* * *}\right)$, and ICT alternative assessment $\left(\beta=.19^{* *}\right)$. This finding means that the teacher's CIL mastery strongly affects his use of the computerized system for pedagogic management, less strongly influences his use of ICT teaching strategies and teaching writing in an ICT environment, and relatively less affects his use of ICT alternative assessment .

When testing the influence of "ICT teaching strategies" on "Teaching writing in an ICT environment", it can be seen that the use of diverse ICT teaching strategies strongly affects the use of teaching writing in an ICT environment $\left(\beta=.51^{* * *}\right)$. This variable strongly influences also the use of ICT alternative assessment $\left(\beta=.56^{* * *}\right)$. ICT alternative assessment considerably affects the use of diverse ICT teaching strategies $(\beta=.27 * * *)$, but does not influence the use of the computerized system for pedagogic management $(\beta=.10)$. Another interesting finding is that the use of the computerized system for pedagogic management affects to some extent the use of diverse ICT teaching strategies.

SEM analysis demonstrates as well the indirect influences of the variables, as compared to the direct influences in the model. It can be seen from the analysis that:

1. Teaching writing in an ICT environment is strongly indirectly influenced by CIL mastery, via 
the use of diverse ICT teaching strategies. The indirect influence is stronger than the direct $(\beta=.34 * * *$ and $\beta=.25 * * *$ respectively). This means that the use of diverse ICT teaching strategies significantly influences teaching writing in an ICT environment, and the influence is stronger than that of CIL mastery.

2. ICT alternative assessment is strongly indirectly influenced by CIL mastery, via teaching writing in an ICT environment. The indirect influence is stronger than the direct $(\beta=.25 * * *$ and $\beta=.19^{* *}$ respectively). This means that teaching writing in an ICT environment significantly influences ICT alternative assessment, and the influence is stronger than that of CIL mastery.

3. The use of the pedagogic management tool is strongly directly influenced by CIL mastery. The direct influence is stronger than the indirect via alternative on-line evaluation $(\beta=.52 * * *$ and $\beta=.19^{* * *}$, accordingly). This means that the influence of CIL mastery on the use of the pedagogic management tool is significant and stronger than that of alternative on-line evaluation.

4. The use of diverse on-line teaching strategies is strongly indirectly influenced by CIL mastery, via the use of the pedagogic management tool. The indirect influence is stronger than the direct ( $\beta=.52 * * *$ and $\beta=.34 * * *$, accordingly). This means that CIL mastery significantly influences the use of diverse on-line teaching strategies, and the influence is stronger than that of the use of the pedagogic management tool.

5. Additionally, the use of diverse ICT teaching strategies is strongly directly influenced by ICT alternative assessment, more than indirectly via the use of the computerized system for pedagogic management $(\beta=.27 * * *$ and $\beta=.10$ respectively). This means that ICT alternative assessment significantly influences the use of diverse ICT teaching strategies, and the influence is stronger than that of the use of the computerized system for pedagogic management.

To summarize, the SEM analysis demonstrates, that the teachers' CIL mastery directly influences all the components of the process of knowledge structuring in an ICT environment. In the same time, it serves as an important mediating factor in the level of performance and implementation of the process components, with the exception of the use of the computerized system for pedagogic management.

\section{Discussion and Conclusions}

In this study a path analysis, employing the SEM method, was performed. This analysis permits us to look at a rather complex and accurate representation of reality. Thus we can see that the teachers' mastery of CIL literacy is a central factor of structuring the students' knowledge in an ICT environment.
The knowledge structuring process is a component of the constructivist teaching. Constructivist teaching consists of creating a learning space where teacher-student-subject dialogue exists, emphasizing the relevance and authenticity of the study subjects to the student's life, anchoring learning activities in complex assignments, problems, and dilemmas, and lastly, structuring the learning around core concepts. In this teaching approach teachers possess a knowledge which suits the students' needs and a capability to understand and trust them. The basic assumption is that every student is capable of learning and can be guided toward the required achievements [5]. The SEM results support the argument which states that ICT environment is congruent with the new pedagogical paradigm. Actually, this kind of environment turns the classroom into a community of teachers and students, who assume shared responsibility for acquiring and structuring knowledge [12]. The results of the present study also support the argument that the teacher's knowledge is a crucial factor in the process of change taking place in the school [13] [14]. Therefore, CIL can be considered a powerful meaning for introduction of the technological-pedagogical change into the school.

The SEM analysis reveals that the process of knowledge structuring in an ICT environment is circular and includes employment of ICT teaching strategies, teaching writing in an ICT environment, and alternative on-line assessment. This process and its every component are significantly influenced by the level of the teacher's CIL mastery. The results also demonstrate the difficulty experienced by teachers in using the computerized system for pedagogic management during the process.

Some researches claim that the development of teachers' CIL plays a decisive role in educating the students in CIL [8] [14].This may indicate that the use of the tool does not assist the alternative assessment in particular and the constructivist approach in general.

The results of the present study reflect the complexity of the process of knowledge structuring in an ICT environment, similarly to findings of prior research [12]. They also emphasize the importance of interdependency between all the components of the process and between each component and the teacher's CIL mastery. Following these findings, it is recommended to continuously promote and develop CIL among the teachers. This should be done directly, as an integral part of a teacher's professional development in our ever-changing reality. In addition, a practical consideration of building a CIL curriculum, both for schools and for higher education, is recommended.

In further research, it is recommended to perform observations and open-ended interviews with 
teachers, in order to collect in-depth information about the circular-spiral structuring of teachinglearning-evaluation in a computerized environment.

\section{References}

[1] Arbuckle, J. L. (2013). AMOS 22.0 User's Guide. Chicago: SPSS Inc.

[2] Birnbaum, M. (2012). Continuously structuring. Retrieved September 1, 2015, from http://www.cet.ac.il/ self-regulation/Units/unit2-expand2.htm (Hebrew)

[3] Blau, I., Peled, Y., \& Nusan, A., (2014). Technological, pedagogical and content knowledge in one-to-one classroom: teachers developing "digital wisdom". Interactive Learning Environments, 1-16. Retrieved September 1, 2015, from http://www.tandfonline.com/ doi/abs/10.1080/10494820.2014.978792?journalCode=nile 20\#.VSYtb9ysWvQ.

[4] Catts, R. \& Lau, J. (2008). Towards Information Literacy Indicators. Paris, UNESCO.

[5] Darling-Hammond, L., \& Youngs, P., (2002). Defining "highly qualified teachers": What does "scientificallybased research" actually tell us? Educational Researcher, 31(9), 13-25.

[6] Ertmer, P. A., \& Ottenbreit-Leftwich, A. T., (2010). Teacher technology change: How knowledge, confidence, beliefs, and culture intersect. Journal of Research on Technology in Education, 42 (3), 255-284.

[7] Fraillon, J., \& Ainley, J., (2010). The IEA International Study of Computer and Information Literacy (ICILS). Retrieved 7/9/2011 from http://forms.acer.edu.au/ icils/documents/ICILS-Detailed-Project-Description

[8] Fraillon, J., Ainley, J., Schulz, W., Friedman,T., \& Gebhardt, E. (2014). International Computer and Information Literacy Study, Preparing for Life in a Digital Age, The IEA International Computer and Information Literacy Study International Report. SpringerLink.com.Open Access. Retrieved from http://www.iea.nl/fileadmin/user_upload/Publications/Elec tronic_versions/ICILS_2013_International_R eport.pdf

[9] Fraillon, J., Schulz, W., \& Ainley, J., (2013). International Computer and Information Literacy Study assessment framework. Amsterdam, the Netherlands: International Association for the Evaluation of Educational Achievement (IEA). Retrieved from http://www.iea.nl/fileadmin/user_upload/Publications/ Electronic_versions/ICILS_2013_Framework.pdf

[10] Fullan, M., (2011). The moral imperative realized. Thousand Oaks, CA: Corwin Press; Toronto: Ontario Principals Council.

[11] Halverson, R., \& Smith, A., (2010). How new technologies have (and have not) changed teaching and learning in school. Journal of Computing in Teacher Education, 26(2), 16-49.
[12] Hong, H.Y., Scardamalia, M., \& Zhang, J. (2010). Knowledge Society Network: Toward a dynamic, sustained network for building knowledge. Canadian Journal of Learning and Technology, 36 (1). Retrieved from http://www.cjlt.ca

[13] Kisirkoi, F. K. (2015). Integration of ICT in Education in a Secondary School in Kenya: A Case Study Literacy Information and Computer Education Journal, 6(2). Retrieved November 24, 2015, from http://infonomics-society.ie/wp-content/uploads/licej/ published-papers/volume-6-2015/Integration-of-ICT-inEducation.pdf

[14] Koehler, M., \& Mishra, P., Kereluik, K., Shin, T. S., Graham, C. R., (Eds.) (2014). Handbook of research on educational communications and technology. New York: Springer.

[15] Magen-Nagar, N., \& Shamir-Inbal, T., (2014). National ICT program - a lever to change teachers' work. American Journal of Educational Research, 2(9), 727-734.

[16] Mikropoulos, T. A., \& Natsis, A., (2011). Educational virtual environments: A ten-year review of empirical research (1999-2009). Computers \& Education, 56, 769780.

[17] Ministry of Education, Israel, (2012). The National Plan - adapting the educational system to the $21^{\text {st }}$ century vision and rationale. Ministry of Education, Israel. Retrieved on September 1, 2015, from http://cms.education.gov.il/EducationCMS/Units/MadaTec h/hatamat_marechet_21 (Hebrew)

[18] Mishra, P., Fahnoe, C., Henriksen, D., \& The DeepPlay Research Group, (2013). Creativity, Self-directed Learning, and the Architecture of Technology Rich Environments. TechTrends, 57(1), 10-13.

[19] Pellegrino, J. W., \& Hilton, M. L. (Eds.). (2012). Education for Life and Work: Developing Transferable Knowledge and Skills in the 21st Century. Committee 011 Defining Deeper Learning and 21' Centuiy Skills. National Research Council of the National Academies.

[20] Voogt, J., (2012). ICTs for curriculum change, iite policy brief. Published by the UNESCO Insti tute for Informati on Technologies in Education 8 Kedrova St., Bldg. 3, Moscow. http://iite.unesco.org/pics/ publications/en/files/3214717.pdf

\section{Appendix 1}

\section{Pedagogic-technological questionnaire}

Dear teacher,

Before you is a questionnaire intended to evaluate the extent to which you use an ICT environment for teaching and learning needs, and thus to obtain information for professional development in the program known as "Adapting het education system to the $21^{\text {st }}$ century skills". 
Please complete the questions carefully, and on conclusion press the "submit" button.

Thank you in advance for your cooperation

\section{Part 1 Complete regarding yourself}

- Type of school (elementary/junior high school)

- Locale

- District

- Gender

- Subject taught

- Academic education

- Number of years of teaching seniority

\section{Part 2}

Note the degree of your knowledge and your use of it: 1 - not at all; 2 - very little; 3 - somewhat; 4 to very a great extent

\section{Degree of use of ICT tools}

1.1 Managing files

1. Organizing, locating, and seeking information in folders on the disk on key

2. Handling file: saving, copying, deleting

3. Installing and removing programs and digital tools

4. Printing a document: choosing a printer and number of copies

1.2 Word processing

5. Writing and design of text

6. Adding autoshapes, use of drawing ruler and word art design

7. Adding picture, altering font size, choosing a section from it

8. Adding table and its design, text wrap, return to headings

9. Adding hyperlink (to the site, file, other place in the document, bookmark)

10. Working with levels of text (e.g., creating a page of contents)

\subsection{Preparing a presentation}

11. Creating slides comprising text, graphics, pictures

12. Creating references within a presentation: to a site, to a file, slides

13. Adding a filmstrip, picture, animation, voice

14. Editing embedded video files

\subsection{Electronic spreadsheet}

15. Writing a textual or numerical value in the spreadsheet cells

16. Use of simple functions: average, sum

17. Use of chart wizard to create a graph

18. Sorting the data

1.5 Internet surfing

19. Search for information using a search engine

20. Cataloguing favorite sites in folders you created

21. Downloading/saving files and pictures from the internet

22. Locating videos and visual representations on the web

1.6 Network communications

23. Using social networks (e.g., Twitter, Facebook)

24. Uploading personal and cooperative information to the network

25. Use of email: receiving sending, forwarding, attaching file

26. Email address book

27. Editing files in the cooperative network space

28. Writing responses in a forum or blog

1.7 Tools for pedagogic management

29. Reporting attendance in the pedagogic management tool

30. Creating evaluation reports in the pedagogic management tool

31. Use of information management system to produce reports and determine learning tracks in the learning environment such as OFEK, GALIM, ELNET, Et HaDaat

\section{Teaching in an ICT environment}

2.1 Teaching strategies in a computerized environment

32. I use a computer and a projector and/or computers in my classroom to present, explain or illustrate information

33. I put learning assignments and/or content on the school site

34. I usually give my students computerized assignments intended for practice and repetition, for solving problems and for using sources of information

35. I develop computerized assignments in diverse subjects (at least 2 assignments annually)

36. I guide my students to be aware of possible dangers connected to the use of the internet such as invasion of their privacy, addiction to the network, copyright, intellectual property, slander etc.

\subsection{Writing in a computerized environment}

37. I use computerized tools (word processor) for writing documents, activity sheets, papers, tests etc.

38. I develop writing assignments using diverse ICT tools for my students: Word processing, presentations, blogs, discussion groups

39. I use the various digital functions to 
advance my students' writing (correcting writing mistakes, writing comments, saving drafts, dictionary etc.

40. I direct my students to manage a digital portfolio of their work

41. I offer my students shared writing tasks using tools that enable shared writing such as discussion groups, wiki, blogs

42. I teach my students skills for rewriting and editing text (layout, paragraphs, numbering)

\subsection{Evaluating students in an ICT} environment

43. I use assignments and/or computerized tests that I prepared by myself to evaluate my students

44. I use ready assignments and/or computerized tests to evaluate my students

45. I evaluate my students using a digital portfolio

46. I use computerized tools to gather data for evaluation and tracking my students' progress

47. I provide feedback to my students using ICT tools such as email, forums, blogs, wiki

48. I use computerized tools to analyze and process findings to draw conclusions

49. I publish the students' results on the network for colleague evaluation 